\title{
Antimicrobial Efficiency of Selected Wastes and By- Products for Building Applications
}

\author{
Július Strigáč ${ }^{1 *}$, Jozef Mikušinec ${ }^{1}$ and Nadežda Števulová ${ }^{2}$ \\ ${ }^{1}$ Production and Technical Department, Povazska cement plant Ladce, Slovakia \\ ${ }^{2}$ Department of Material Engineering, Institute of Environmental Engineering, Slovakia
}

*Corresponding author: Július Strigáč, Production and Technical Department, Považská cementáreň a. s. Ladce (Povazska cement plant Ladce), Slovakia

\begin{abstract}
Article deals firstly with studying antimicrobial efficiency of ground metallurgical slags: granulated blast-furnace slag, aircooled blast-furnace slag, demetallized steel slag, calcareous ladle slag and copper slag. The efficiency was tested on microbial representatives: $\mathrm{G}^{+}$and $\mathrm{G}^{-}$bacteria; yeasts; fungi. The efficiency was determined by dilution methods in agar growth media with resulting slag concentrations of $10,20,40$ and $60 \%$. The results gained by testing the antimicrobial efficiency of individual slag samples on selected representatives of biodeteriogenic microflora can be summarized as follows: the tested slag samples are characterized by selective toxicity on the model bacteria, yeasts, and microscopic filamentous fungi. Calcareous ladle slag possesses the highest antimicrobial efficiency, while granulated blast-furnace slag and demetallized steel slag have medium activity. Air cooled blast-furnace slag has still lower activity and copper slag has the lowest activity. Secondly, antifungal effects of fluidized bed combustion fly and bottom ash, pulverized fly ash, carbide lime slurry, commercial lime and granulated blast-furnace slag as well as cements made from it were tested on fungi according to technical standard ČSN 72 4310. The study confirms fungistatic properties of all samples as well as Blastfurnace cements containing the granulated blast-furnace slag additions from $65 \mathrm{wt} . \%$ to $95 \mathrm{wt}$. $\%$, with exception of pulverized fly ash and Blastfurnace cements containing the granulated blast-furnace slag additions lower than $65 \mathrm{wt} . \%$, which have no fungistatic properties.
\end{abstract}

Keywords: Metallurgical slags; Antimicrobial efficiency; Mould-proof properties; Fungistatic properties; Fluidized bed combustion fly and bottom ash; Pulverized coal combustion fly ash; Carbide lime slurry; Fungistatic cements

\section{Introduction}

Every year increasing enormous amounts of wastes and industrial by-products are generated worldwide, which result in environmental problems. Their high cost disposal or low effective recovery and utilization lead to depositing in a landfill site. However, wastes and by-products can represent an important source of secondary raw materials in order to replace natural resources. The representatives of such materials can be metallurgical slags, coal combustion ashes, carbide lime slurries etc. Typical for these materials can be mentioned ground metallurgical slags: granulated blast-furnace slag with finenesses 340 (1Sa) and $520 \mathrm{~m}^{2} \cdot \mathrm{kg}^{-1}$ (1Sb), air-cooled blast-furnace slag (2S), demetallized steel slag (3S), calcareous ladle slag (4S) and copper slag (5S) as well as fluidized bed combustion fly (FBCFA) and bottom ash (FBCBA), pulverized fly ash (PCCFA), carbide lime slurry (CLS). Reuse of these materials for new applications is of great international interest. The antimicrobial properties, focusing on antifungal effects of the wastes and by-products have been previously studied [1-4]. Results of these investigations have shown that some of these materials possess significant antimicrobial efficiency and thereunto fungistatic properties and so can be readily used for building materials and products providing them increasing resistance against biodeterioration.

Biocorrosion, subsequently connected with biodeterioration of concretes, mortars, and building materials and products is a serious problem wherever the conditions suitable for particular microorganisms occur. Biodeterioration reduces the utility efficiency of concretes, as well as their service life. Biocorrosion, as a specific type of chemical corrosion, is caused by various biogenic organic acids and mineral acids (sulphuric acid, $\mathrm{H}_{2} \mathrm{SO}_{4}$, and nitric acid, $\mathrm{HNO}_{3}$ ), as well as by corrosive hydrogen sulphide, 
$\mathrm{H}_{2} \mathrm{~S}$, and ammonia, $\mathrm{NH}_{3}$, which result from the metabolic activity of microorganisms [5-8]. These aggressive metabolites react mainly with calcareous components of concrete and mortar stone, with development of their non-binding calcareous salts. Some of them cause sulphate degradation, resulting in extreme expansion in the hardened concrete and leading to the complete destruction of concrete structural elements.

The article aims to review the previously measured results of antimicrobial efficiency of selected wastes and industrial byproducts for increasing their utilization in building materials and products, as well as for enlarging civil engineering applications with respect to higher biodeterioration resistance and sustainable development.

\section{Materials and Methods}

\section{Materials}

The tested wastes and industrial by-products have been as follows: granulated blast-furnace slag with finenesses 340 (1Sa) and $520 \mathrm{~m}^{2} \cdot \mathrm{kg}^{-1}(1 \mathrm{Sb})$, air cooled blast-furnace slag (2S), demetallized steel slag (3S), calcareous ladle slag (4S), copper slag (5S) [1], fluidized bed combustion fly ash (FBCFA) and bottom ash (FBCBA), pulverized coal combustion fly ash (PCCFA) [2], carbide lime slurry (CLS), industrially manufactured commercial lime (IMCL) [3] as well as ground granulated blast furnace slag (GGBS) and the cements made from it (mixtures of GGBS, ground Portland cement clinker (PCC) and gypsum (Gyps)) [4], respectively. The samples were ground to the finenesses of $400 \mathrm{~m}^{2} \cdot \mathrm{kg}^{-1}$.

Table 1: Chemical composition of ground samples in wt.\% used for testing.

\begin{tabular}{|c|c|c|c|c|c|c|c|c|c|c|}
\hline wt.\% & $\mathbf{S i O}_{2}$ & $\mathbf{A l}_{2} \mathbf{O}_{\mathbf{3}}$ & $\mathbf{F e}_{\mathbf{2}} \mathbf{O}_{\mathbf{3}}$ & $\mathbf{C a O}$ & $\mathbf{M g O}$ & $\mathbf{N a}_{\mathbf{2}} \mathbf{0}$ & $\mathbf{K}_{\mathbf{2}} \mathbf{0}$ & $\mathbf{S O}_{\mathbf{3}}$ & $\mathbf{C l}$ & $\mathbf{L . 0 . I}$ \\
\hline $\mathrm{S} 1$ & 42.17 & 6.87 & 0.32 & 41.92 & 10.39 & 0.17 & 0.6 & 1.84 & 0.0173 & 0.95 \\
\hline $\mathrm{S} 2$ & 40.57 & 8.12 & 2.81 & 41.73 & 8.44 & 0.19 & 0.72 & 2.39 & 0.0112 & 0.09 \\
\hline $\mathrm{S} 3$ & 12.81 & 1.64 & 29.78 & 52.3 & 2.54 & 0.07 & 0.04 & 0.28 & 0.0138 & 6.02 \\
\hline S4 & 13.97 & 17.77 & 1.9 & 58.97 & 3.3 & 0.07 & 0.06 & 1.98 & 0.0017 & 5.32 \\
\hline S5 & 27.26 & 7.01 & 46.64 & 7.48 & 1.9 & 1.07 & 0.4 & 0.15 & 0.0012 & 4.3 \\
\hline FBCFA & 40.99 & 21.24 & 7.8 & 25.86 & 3.22 & 0.31 & 0.99 & 9.07 & 0.02 & 3.11 \\
\hline FBCBA & 36.23 & 17.05 & 5.49 & 32.99 & 2.74 & 0.11 & 1.21 & 16.36 & 0.01 & 0.93 \\
\hline PCCFA & 54.44 & 27.38 & 6.71 & 4.43 & 2.43 & 0.08 & 3.49 & 1 & 0.007 & 1.49 \\
\hline CLS & 2.24 & 1.32 & 0.15 & 66.64 & 0.38 & 0.93 & 0.08 & 0.42 & 0.0101 & 27.7 \\
\hline IMCL & 1.08 & 0.42 & 0.26 & 65.28 & 9.88 & 0.41 & 0.14 & 0.13 & 0.0058 & 22.22 \\
\hline GGBS & 39.5 & 6.8 & 0.7 & 38.1 & 9.6 & 0.6 & 0.4 & 1.8 & 0.018 & 0.9 \\
\hline PCC & 20.9 & 4.6 & 3.4 & 65.8 & 1.3 & 0.1 & 0.9 & 0.5 & 0.02 & 1 \\
\hline Gyps & 0.4 & 0.2 & 0.2 & 31.9 & 0.02 & 0.05 & 0.07 & 45.9 & 0.008 & 21.1 \\
\hline
\end{tabular}

L.O.I. - Loss on Ignition.

The chemical composition of samples was analysed by X-ray fluorescence analysis (XRF) according to EN 196-2 using a SPECTRO X-LAB 2000 apparatus. The semi-quantitative chemical composition of the samples is introduced in Table 1.

The mineralogical composition of the samples was determined by XRD technique using BRUKER AXS D8 Advance device. The identified mineralogical composition of the samples is as follows: $\mathrm{S} 1 \mathrm{a}$ and $\mathrm{S} 1 \mathrm{~b}$ - melilite (solid solution of $\mathrm{C}_{2} \mathrm{AS}-\mathrm{C}_{2} \mathrm{MS}_{2}$ ); $\mathrm{S} 2$ - melilite $\mathrm{C}_{2} \mathrm{AS}-\mathrm{C}_{2} \mathrm{MS}_{2}$, brownmillerite $\mathrm{C}_{4} \mathrm{AF}$, quartz $\mathrm{SiO}_{2}$; $\mathrm{S} 3$ - wüstite $\mathrm{FeO}$, brownmillerite $\mathrm{C}_{4} \mathrm{AF}$, free lime $\mathrm{CaO}$, portlandite $\mathrm{Ca}(\mathrm{OH})_{2}$, larnite $\beta-C_{2} \mathrm{~S}$, quartz $\mathrm{SiO}_{2} ; \mathrm{S} 4$ - free lime $\mathrm{CaO}$, larnite $\beta-\mathrm{C}_{2} \mathrm{~S}$, shanonite $\gamma$ - $\mathrm{C}_{2} \mathrm{~S}$, gehlenite $\mathrm{C}_{2} \mathrm{AS}, \mathrm{C}_{3} \mathrm{~A}$, gypsum $\mathrm{CaSO}_{4} \cdot 2 \mathrm{H}_{2} \mathrm{O}$, quartz $\mathrm{SiO}_{2}$ and $\mathrm{S} 5$ - fayalite $2 \mathrm{FeO} . \mathrm{SiO}_{2}$, anortite $\mathrm{CAS}_{2}$, pyroxene type CaAlAlSiO FBCFA - quartz $\mathrm{SiO}_{2}$, anhydrite $\mathrm{CaSO}_{4}$, free lime $\mathrm{CaO}$, anorthite $\mathrm{CAS}_{2}$, hematite $\mathrm{Fe}_{2} \mathrm{O}_{3}$, magnetite $\mathrm{Fe}_{3} \mathrm{O}_{4}$, glass phase; FBCBA - quartz $\mathrm{SiO}_{2}$, anhydrite $\mathrm{CaSO}_{4}$, free lime $\mathrm{CaO}$, calcite $\mathrm{CaCO}_{3}$, hematite $\mathrm{Fe}_{2} \mathrm{O}_{3}$, magnetite $\mathrm{Fe}_{3} \mathrm{O}_{4}$, glass phase; PCCFA - quartz $\mathrm{SiO}_{2}$, mullite $\mathrm{A}_{3} \mathrm{~S}_{2}$, hematite $\mathrm{Fe}_{2} \mathrm{O}_{3}$, magnetite $\mathrm{Fe}_{3} \mathrm{O}_{4}$, glass phase; CLS - calcite $\mathrm{CaCO}_{3}$ (22.40wt.\%), portlandite $\mathrm{Ca}(\mathrm{OH})_{2}(70.10 w t . \%)$, hydrocalumite (structurally like as Friedel's salt $3 \mathrm{CaO} \cdot \mathrm{Al}_{2} \mathrm{O}_{3} \cdot \mathrm{CaCl}_{2} \cdot 10 \mathrm{H}_{2} \mathrm{O}$ ) $\mathrm{Ca}_{4} \mathrm{Al}_{2}(\mathrm{OH})_{12}(\mathrm{Cl}, \mathrm{OH})_{2} \cdot 4 \mathrm{H}_{2} \mathrm{O}$ (5.13wt.\%), graphite C (2.37wt.\%); IMCL - portlandite $\mathrm{Ca}(\mathrm{OH})_{2}$, calcite $\mathrm{CaCO}_{3}$, quartz $\mathrm{SiO}_{2}$, periclase MgO; GGBS - fully glassy, sometime containing a small amount of melilite $\mathrm{C}_{2} \mathrm{AS}-\mathrm{C}_{2} \mathrm{MS}_{2}$ or merwinite $\mathrm{C}_{3} \mathrm{MS}_{2}$; PCC $-\mathrm{C}_{3} \mathrm{~S}$ (70.5wt.\%), $\mathrm{C}_{2} \mathrm{~S}$ (10.2wt.\%), $\mathrm{C}_{3} \mathrm{~A}$ (5.7wt.\%), $\mathrm{C}_{4} \mathrm{AF}(10.9 \mathrm{wt} . \%)$ and free lime CaO (1.0 wt.\%); Gyps - gypsum $\mathrm{CaSO}_{4} .2 \mathrm{H}_{2} \mathrm{O}$ (min. 95wt.\%), limestone $\mathrm{CaCO}_{3}$ (max. 2.5wt.\%), respectively.

The determination of free calcium oxide $\mathrm{CaO}_{\text {free }}$ content in the metallurgical slags was performed using the hot ethylene glycol titration method [2]. The $\mathrm{CaO}_{\text {free }}$ content in the slags is given in Table 2. The ground slags were leached in distilled water at $20^{\circ} \mathrm{C}$ for $24 \mathrm{~h}$. The $\mathrm{pH}$ was determined in the slag water leachates by an Agilent Technologies 3200P pH Meter with an electrode reference system. The measured $\mathrm{pH}$ values of the water leachates are also shown in Table 2. 
Table 2: The free calcium oxide $\mathrm{CaO}_{\text {free }}$ content in the samples and $\mathrm{pH}$ of the water leachates.

\begin{tabular}{|c|c|c|c|c|c|c|c|c|c|c|}
\hline & S1 & S2 & S3 & S4 & S5 & FBCFA & FBCBA & PCCFA & GGBS1 & GGBS2 \\
\hline $\mathrm{CaO}_{\text {free }}$ & 0 & 0.06 & 0.95 & 3.3 & 0 & 6.59 & 18.53 & 0.08 & - & - \\
\hline $\mathrm{pH}$ & 11.71 & 9.34 & 12.87 & 12.93 & 10.44 & 12.3 & 12.5 & 11.8 & 11.54 & 11.63 \\
\hline
\end{tabular}

GGBS1 - pH of the water leachate at $20^{\circ} \mathrm{C}$; GGBS2 - pH of the water leachate at $100{ }^{\circ} \mathrm{C}$

\section{Methods}

\section{Determination of antimicrobial efficiency of metallurgical slags under in vitro conditions}

The antimicrobial activity of the metallurgical slags S1 - S5 was tested on selected representatives of biodeteriogenic microflora, such as bacteria, yeasts, and filamentous fungi. Microbial strains (bacteria and filamentous fungi) used in this work were either from the Czech Collection of Microorganisms, (CCM) T. G. Masaryk University, Brno, Czech Republic or yeasts from the Collection of Microorganism of the Institute of Biochemistry and Microbiology, Slovak University of Technology, Bratislava, Slovak Republic [1].

The tests were performed in the laboratory incubator at temperatures of $30{ }^{\circ} \mathrm{C}$ for bacteria, $28{ }^{\circ} \mathrm{C}$ for yeasts and $25{ }^{\circ} \mathrm{C}$ for filamentous fungi at a relative humidity of $95 \%$ for four days. Antimicrobial activity was determined by dilution methods in standard agar growth media, so that the resulting concentration of tested slags in growth media was $10,20,40$, and $60 \%$ [1]. The $\mathrm{pH}$ of the growth media with the addition of the slags was strongly alkaline ( $\mathrm{pH}$ 11); thus, half the samples of each slag was tested at this $\mathrm{pH}$, and the second half was tested at a modified $\mathrm{pH}$ (bacteria $\mathrm{pH}$ 7.2, yeasts, and filamentous fungi $\mathrm{pH}$ 6.6). The first half of the samples with the original $\mathrm{pH}$ represented real conditions for growth of microorganisms in concrete; the second half with a modified $\mathrm{pH}$ represented optimal conditions for growth of the microorganisms in vitro [1]. The growth intensity of bacteria and yeasts was compared with the growth of bacteria and yeasts in the control growth media without slags. The growth of filamentous fungi in the presence of slags was monitored by the measurement of average diameter of growing colony at regular time intervals and was compared with the filamentous fungi growth in the control growth media without slags [1].

\section{Method of testing the mould-proof properties of building products and materials}

The antifungal effect of the materials was tested using the procedure given in the technical standard ČSN 724310 [9]. The mould-proof properties expressed as the intensity of fungi growth on building products and materials are determined by both artificial and natural contamination, with exposure to the selected testing moulds under the prescribed conditions presented in [9]. The scale of evaluation of the mould-proof properties of the tested materials according to [9] is expressed by a value from 0 to 5 , which is the degree of fungal growth (DFG). The value 0 means that no growth of fungi occurs and the tested materials possess fungistatic properties; in some cases, fungicide properties also occur after the formation of an inhibiting zone in the broth medium around the sample. The building products and materials are not mould-proof, when the intensity of mould growth on the sample surface itself is from 1 to 5 of DFG.

The testing has been realized in the accredited microbiological laboratory of Testing Institute for Textiles in Brno, Czech Republic. A mixture of fungi - cultures delivered from the Czech collection of microorganisms, has been used for the testing. The test conditions are as follows: sample size $\varnothing 5.5 \mathrm{~cm}$; temperature in the incubator $28 \pm 1{ }^{\circ} \mathrm{C}$; rel. humidity in the incubator $95 \%$; incubation period 3 months; standard broth media. The tested samples have been exposed to the contamination by the chosen microorganisms in the broth medium according to exactly defined conditions given in [9] during 3 months, after which their mould-proof properties have been evaluated.

\section{Results}

\section{Antimicrobial efficiency of individual slag samples}

Firstly, the antimicrobial activity of individual slag samples on selected representatives of biodeteriogenic microflora was determined; subsequently the antimicrobial efficiency of individual slags was mutually compared. The tests were also carried out at A-alkaline $\mathrm{pH}$ of growth media and $\mathrm{N}$-neutral $\mathrm{pH}$ of growth media, as well [1].

Based on the obtained results of determining the antibacterial efficiency of individual slag samples on the selected model Grampositive bacteria $\left(\mathrm{G}^{+}\right)$and Gram-negative bacteria $\left(\mathrm{G}^{-}\right)$, it can be stated that the inhibitory effect of the slag samples differs. Slag S4, which intensely inhibited growth of $\mathrm{G}^{+}$and also $\mathrm{G}^{-}$bacteria, had the highest antibacterial activity, which was also proven at the lowest concentration of slag S4: 10\% in growth media. The bacteria, except M. luteus, did not grow at higher concentrations of slag S4 in growth media, whereas the $\mathrm{pH}$ values of the growth media (alkaline, neutral) did not affect the inhibition intensity of bacterial growth.

The growth of $\mathrm{G}^{+}$bacteria $S$. aureus and B. subtilis was inhibited in the presence of slag S3 in growth media as early as at a concentration of $10 \%$, and at higher concentrations growth was completely inhibited. However, slag S3 did not affect the growth of $\mathrm{G}^{-}$bacteria, except for $E$. coli, at the highest concentration used $(60 \%)$. Inhibition of bacterial growth in the presence of slag S2 was more intensive in the alkaline $\mathrm{pH}$ of growth media. The complete inhibition of the growth of $\mathrm{G}^{+}$bacteria S. aureus and B. subtilis was detected with slag S2 at concentrations of 20,40, and 60\% in growth media and, inhibition of growth of $\mathrm{G}^{-}$bacteria E. coli, S. marcescens and $P$. aeruginosa was detected at a slag S2 concentration of $60 \%$ in growth media. Slag S1a caused total inhibition of $B$. subtilis growth at concentrations of 40 and $60 \%$ in growth media at both a neutral and alkaline pH. A 40 and 60\% concentration of slag S1b in growth 
media at neutral as well as alkaline $\mathrm{pH}$ led to total inhibition of the growth of B. subtilis. No growth of E. coli was observed at a slag S1b concentration of $60 \%$ in growth media at neutral pH. Slag S5 did not significantly affect the growth of the model bacteria. Slags S1a, S1b, S2 and S5 caused a change in S. marcescens growth at alkaline pH. Based on the obtained results, it can be stated that the antibacterial efficiency of the individual slag samples decreased in the order: S4 $>\mathrm{S} 3>\mathrm{S} 2>\mathrm{S} 1 \mathrm{a}=\mathrm{S} 1 \mathrm{~b}>\mathrm{S} 5[1]$.

From the results of determining the anti-yeast efficiency of the individual slag samples on the selected model yeasts, it can be stated, that Slag S4 possessed the highest anti-yeast activity. Growth of all model yeasts was completely inhibited at concentration as low as $10 \%$ of slag S4, at both alkaline and neutral pH of the growth media. Slags S1a, S1b, and S3 caused total inhibition of the growth of all model yeasts from a concentration of $20 \%$ in growth media at alkaline and neutral $\mathrm{pH}$, as well. The growth of the model yeasts was intensively reduced in the presence of slag S2 at concentrations of 40 and $60 \%$ in growth media. Slag S5 partially inhibited the growth of the model yeasts; however, total inhibition of the growth of yeasts was not observed even at the highest concentration of $60 \%$ in growth media. Based on the measured results, the antiyeast efficiency of the individual slag samples decreased in the order: $\mathrm{S} 4>\mathrm{S} 1 \mathrm{a}=\mathrm{S} 1 \mathrm{~b}=\mathrm{S} 3>\mathrm{S} 2>\mathrm{S} 5[1]$.

From the results of determining the antifungal efficiency of the individual slag samples on the selected model filamentous fungi, it is evident that the model filamentous fungi used were sensitive to the presence of slag samples in various ways. As is apparent from the results of inhibition, all slags inhibited the growth of filamentous fungi by $40-100 \%$ at a concentration of $60 \%$ slag. The most sensitive to the presence of all slags were A. niger and T. viride. Their growth was completely inhibited when $20-60 \%$ concentrations of all slag samples at neutral and alkaline $\mathrm{pH}$ were used. The growth of these two fungi species was stopped, thus causing a fungistatic effect. A $60 \%$ concentration of slag S4 led to the inhibition of T. viride growth with fungicide effect (killed fungal spores). Slag S4 had the most inhibiting activity for all fungi. It completely inhibited growth of almost all model filamentous fungi in concentrations from 20$60 \%$ at alkaline $\mathrm{pH}$, with mostly a fungistatic effect. Only T. viride growth was inhibited totally with a fungicide effect at alkaline $\mathrm{pH}$ of growth media at a slag S4 concentration of $60 \%$. At neutral pH of growth media, the growth of model filamentous fungi was inhibited completely at concentrations from $40-60 \%$ of slag S4 and at slag S4 concentration of $60 \%$ with fungicide effect on A. alternata, A. niger, T. viride and Ch. globosum.

A lower inhibiting effect on filamentous fungi growth was observed in the case of slags S1a, S1b and S3, but they inhibited the growth of all tested filamentous fungi from $40-100 \%$ at a concentration of $40 \%$. The lowest impact on the growth of model filamentous fungi was observed in the presence of slags S2 and S5 in growth media, which affected only the growth of the most sensitive fungi, A. niger and T. viride. The most resistant was A. alternata. Its growth was most intensely inhibited by slag $S 4$, with total inhibition observed at $40-60 \%$ of slag, with mostly a fungistatic effect.

Regarding the fact that model filamentous fungi were selectively sensitive to the presence of the tested slags, it is possible to determine only an approximate order of inhibition efficiency of the slags to filamentous micromycetes: $\mathrm{S} 4>\mathrm{S} 3=\mathrm{S} 1 \mathrm{a}=\mathrm{S} 1 \mathrm{~b}>\mathrm{S} 5>\mathrm{S} 2$. The $\mathrm{pH}$ values of the growth media did not significantly influence the intensity of inhibition of the model microorganisms' growth [1].

The results gained by testing the antimicrobial efficiency of individual slag samples on selected representatives of biodeteriogenic microflora can be summarized as follows: the tested slag samples are characterized by selective toxicity on the model bacteria, yeasts, and microscopic filamentous fungi; calcareous ladle slag (S4) possesses the highest antimicrobial efficiency; slag S4 best inhibits the growth of bacteria, yeasts, and microscopic filamentous fungi of all tested slags; total growth inhibition of Trichoderma viride and Aspergillus niger was detected in the presence of all tested slags at a concentration of $10 \%$ in growth media, except for copper slag (S5); the calcareous ladle slag (S4) and granulated blast-furnace slag (S1a) possessed fungicidal (lethal) effect on spores of some filamentous fungi at a concentration of $60 \%$ in growth media; copper slag (S5) is characterized by the lowest antibacterial and anti-yeast efficiency, despite having the highest $\mathrm{Cu}, \mathrm{Cr}, \mathrm{As}, \mathrm{Zn}, \mathrm{Pb}$, and $\mathrm{Hg}$ contents from all tested slags; air cooled blast-furnace slag (S2) and copper slag (S5) have the lowest antifungal efficiency [1]. Slag S4 is characterized as having the highest $\mathrm{CaO}$ content of 58.97 wt.\% and the highest $\mathrm{CaO}_{\text {free }}$ content (3.30wt.\%) as well as the highest $\mathrm{pH}$ (12.93), in comparison with the other tested slags (Table 2). Calcareous ladle slag (S4) has the highest antimicrobial efficiency, while granulated blast-furnace slag (S1a, S1b) and demetallized steel slag (S3) have medium activity. Air cooled blast-furnace slag (S2) has still lower activity and copper slag (S5) has the lowest activity.

\section{The mould-proof properties of the selected wastes and by-products}

After the 3-month incubation period, the mould-proof properties of tested samples were evaluated by the degree of fungi growth (DFG) according to technical standard [9] and the results are summarized in Tables 3 \& 4 . The samples possess different mould-proof properties, most of them is characterized in 0 value of the degree of fungal growth (DFG) i.e. there was no growth of fungi on sample surface.

Table 3: Antifungal properties of the tested samples.

\begin{tabular}{|c|c|c|c|c|c|c|}
\hline Sample & FBCFA & FBCBA & PCCFA & GGBS & CLS & IMCL \\
\hline DFG & 0 & 0 & 5 & 0 & 0 & 0 \\
\hline
\end{tabular}

DFG - degree of fungal growth on the sample surface, 0 - absence of fungal growth, 5 - fungal growth $=100 \%$ 
Table 4: Antifungal properties of ternary mixtures of GGBS, PCC and Gyps.

\begin{tabular}{|c|c|c|c|c|c|c|c|c|c|}
\hline Mixture & $\mathbf{1}$ & $\mathbf{2}$ & $\mathbf{3}$ & $\mathbf{4}$ & $\mathbf{5}$ & $\mathbf{6}$ & $\mathbf{7}$ & $\mathbf{8}$ & $\mathbf{9}$ \\
\hline GGBS & 5 & 20 & 30 & 40 & 60 & 63 & 65 & 70 & 80 \\
\hline PCC & 95 & 80 & 70 & 60 & 40 & 32 & 35 & 30 & 20 \\
\hline Gyps* & 3.4 & 3.3 & 3.1 & 2.9 & 2.6 & 2.5 & 2.4 & 2.3 & 2.2 \\
\hline DFG & 2 & 2 & 1 & 1 & 1 & 1 & 0 & 0 & 0 \\
\hline
\end{tabular}

*Gyps is expressed as sulphate content $\mathrm{SO}_{3}$ wt. \% added into the binary GGBS and PCC mixtures.

The FBCFA, FBCBA and PCCFA possess different mould-proof properties, depending on the amount of free lime $\mathrm{CaO}$ [2]. The results imply that the higher the amount of free lime $\mathrm{CaO}$ in the ash, the more antimicrobially active the particular ash becomes. The mould-proof properties of the FBCFA and FBCBA reach 0 degree of fungi growth [2], they have a fungistatic effect according to technical standard [9]. The results for the mould-proof properties of PCCFA reach 5 degree of fungi growth i.e. PCCFA does not have a fungistatic effect and the sample surface is fully covered by fungi (fungi colonies cover $100 \%$ of the sample surface). However, FBCFA and FBCBA increases $\mathrm{pH}$ values of the water leachate up to 12.3 and 12.5 , which affects the viability of microorganisms [2].

Generally speaking, CLS and IMCL are suitable for reaching 0 degree of fungi growth according to technical standard [9]. On the basis of the experimental results, it can thus be stated that the CLS and IMCL are defined as the fungistatic building materials [3] according to technical standard [9].

GGBS with 0 degree of fungi growth is fungistatic building materials [4] according to technical standard [9]. The ternary mixtures of GGBS, PCC and gypsum possess different mould-proof properties, depending on the amount of GGBS that was added to the mixture (Table 4). The results imply that the higher the amount of GGBS in the mixture, the more antimicrobially active the particular cement mixture becomes. With GGBS content in the mixtures of $65 \mathrm{wt} . \%$ and higher, the mould-proof properties of the cements reach 0 degree of fungi growth.

In general, GGBS, CEM III/A 32,5 N (with GGBS content of 65 wt.\%), CEM III/B 32,5 $\mathrm{N}$ and CEM III/C 32,5 N are suitable for reaching 0 degree of fungi growth [4] and they are defined as fungistatic building materials according to technical standard [9]. The inhibiting zone did not form on the agar around all of the tested samples. This means that the tested samples do not have a fungicidal effect. From a practical point of view, the fungistatic wastes and by-products are suitable for achieving a mould-free environment and potentially offer wide application possibilities in the building industry from preventive use to the purposes of repairing and reconstruction. However, the mechanism of the antimicrobial effects of the tested samples should be a subject of further study.

\section{Conclusion}

From the results of determining the antimicrobial efficiency of individual slag samples, it can be stated, that calcareous ladle slag (4S) intensely inhibited growth of $\mathrm{G}^{+}$and also $\mathrm{G}^{-}$bacteria, had the highest antibacterial activity, which was also proven at the lowest concentration of slag S4: 10\% in growth media. Slag S4 possessed the highest anti-yeast activity. Growth of all model yeasts was completely inhibited at concentration as low as $10 \%$ of slag S4, at both alkaline and neutral pH of the growth media. Slag S4 had the most inhibiting activity for all fungi. It completely inhibited growth of almost all model filamentous fungi in concentrations from $20-60 \%$ at alkaline $\mathrm{pH}$, with mostly a fungistatic effect and at slag S4 concentration of $60 \%$ with fungicide effect on some of the selected model filamentous fungi. On the contrary, copper slag (5S) did not significantly affect the growth of the model bacteria. Slag S5 partially inhibited the growth of the model yeasts; however, total inhibition of the growth of yeasts was not observed even at the highest concentration of $60 \%$ in growth media. The lowest impact on the growth of model filamentous fungi was observed in the presence of air-cooled blast-furnace slag (2S) and slag S5 in growth media.

Based on the obtained results, the antibacterial efficiency of individual slag samples decreased in the order: $\mathrm{S} 4>\mathrm{S} 3>\mathrm{S} 2>\mathrm{S} 1 \mathrm{a}$ $=\mathrm{S} 1 \mathrm{~b}>\mathrm{S} 5$. The decrease in anti-yeast efficiency of the individual slag samples was in the order: $\mathrm{S} 4>\mathrm{S} 1 \mathrm{a}=\mathrm{S} 1 \mathrm{~b}=\mathrm{S} 3>\mathrm{S} 2>\mathrm{S} 5$. Model filamentous fungi were selectively sensitive to the presence of tested slags, but it is only possible to determine the approximate order of inhibition efficiency of slags to filamentous micromycetes: $\mathrm{S} 4>\mathrm{S} 3=\mathrm{S} 1 \mathrm{a}=\mathrm{S} 1 \mathrm{~b}>\mathrm{S} 5>\mathrm{S} 2$.

The study confirmed the fungistatic properties of of fluidized bed combustion fly (FBCFA) and bottom ash (FBCBA), carbide lime slurry (CLS), commercial lime (IMCL) and granulated blastfurnace slag (GGBS) as well as Blastfurnace cements containing the granulated blast-furnace slag additions from $65 \mathrm{wt} \%$ to $95 \mathrm{wt} . \%$, with exception of pulverized fly ash (PCCFA) and Blastfurnace cements containing the granulated blast-furnace slag additions lower than $65 \mathrm{wt} . \%$, which have no fungistatic properties. The study of mould-proof properties can be summarized: FBCFA, FBCBA, CLS, IMCL, GGBS, Cements with GGBS content of 65 wt.\% and more are fungistatic building materials according to technical standard ČSN 724310.

\section{References}

1. Strigáč J, Števulová N, Mikušinec J, Varečka L', Hudecová D (2018) Antimicrobial efficiency of metallurgical slags for application in building materials and products. Buildings 8(33): 1-14.

2. Strigáč J, Števulová N, Mikušinec J, Sobolev K (2018) The fungistatic properties and potential application of by-product fly ash from fluidized bed combustion. Constr Build Mater 159: 351-360. 
3. Strigáč J, Mikušinec J, Strigáčová J, Števulová N (2017) The antifungal efficiency of carbide lime slurry compared with the commercial lime efficiency. IOP Conf. Ser.: Earth and Environ Sci 92(012058): 1-5.

4. Strigáč J, Martauz P (2016) Fungistatic properties of granulated blastfurnace slag and related slag-containing cements. Ceramics-Silikáty 60(2): 19-26.

5. Cwalina B (2008) Biodeterioration of concrete. Architect Civ Eng Environ 1(4): 133-140.

6. George RP, Vishwakarma V, Samal SS, Mudali UK (2012) Current understanding and future approaches for controlling microbially influenced concrete corrosion: A review. Concr Res Lett 3(3): 491-506.
7. House MW, Weiss WJ (2014) Review of microbially induced corrosion and comments on needs related to testing procedures. The $4^{\text {th }}$ International Conference on the Durability of Concrete Structures, USA.

8. Strigáč J, Martauz P, Eštoková A, Števulová N, Luptáková A (2016) Biocorrosion resistance of concretes containing antimicrobial ground granulated blastfurnace slag BIOLANOVA and novel hybrid H-CEMENT. Solid State Phenom 244: 57-64.

9. Czechoslovakian Standards Institution (1977) ČSN 72 4310. The testing of mould proofness of building products and materials, CSSI, Prague, Czechoslovakia.

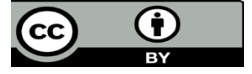

This work is licensed under Creative Commons Attribution 4.0 License

To Submit Your Article Click Here:

Submit Article

DOI: $10.32474 /$ TCEIA.2019.03.000162

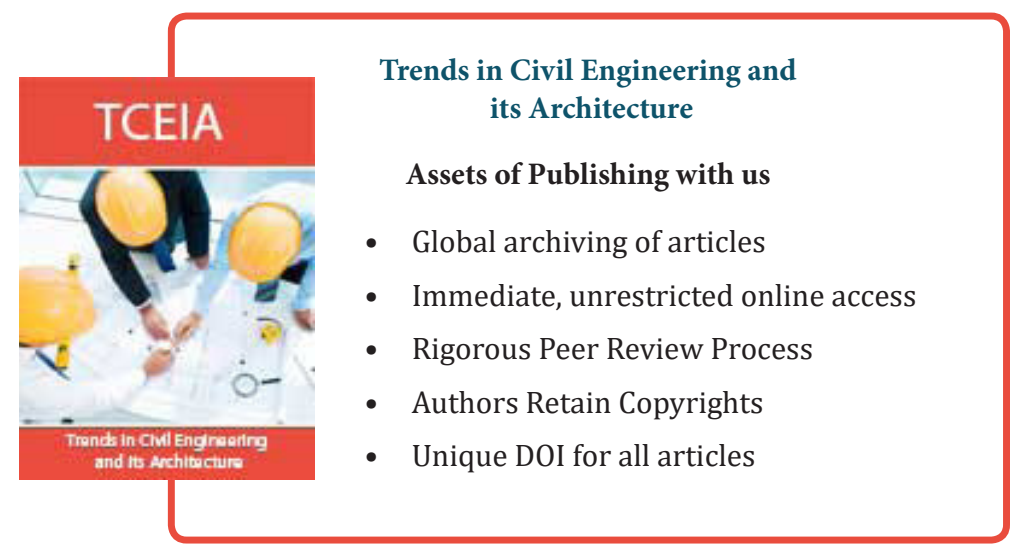

